\title{
Anti-Money Laundering Rules and the Future of Banking Secrecy Laws: Evidence from Lebanon
}

\author{
Carole Serhan \\ Dept. of Business Management and Administration, University of Balamand \\ Balamand, Lebanon \\ E-mail: carole.serhan@balamand.edu.lb
}

Sandy Mikhael

Dept. of Business Management and Administration, University of Balamand Balamand, Lebanon

E-mail: sandy.mikhael@std.balamand.edu.lb

Silvana El Warrak

Dept. of Business Management and Administration, University of Balamand

Balamand, Lebanon

E-mail: silvana.elwarrak@std.balamand.edu.lb

Received: Oct. 17, 2016 Accepted: Nov. 7, $2016 \quad$ Published: Nov. 21, 2016

doi:10.5296/ifb.v3i2.10165 ～URL: http://dx.doi.org/10.5296/ifb.v3i2.10165

\begin{abstract}
This research aims to examine the banking secrecy laws and analyze their effects on the anti-money laundering rules in Lebanon. Banking secrecy laws have always been an advantage for customers, while anti-money laundering procedures have been considered as safety measures to guarantee community security. Certainly, reaching an appropriate balance is a dilemma which many legislative authorities face. Through this research, primary and secondary data are gathered as both are needed to create an overview of the extant situation. Indeed, the existing Lebanese laws related to banking secrecy and anti-money laundering rules are identified. In addition, a qualitative study is conducted through interviewing four Lebanese banks' directors that were selected based on the purposive sampling technique.
\end{abstract}




\section{Macrothink}

Analysis through using NVivo software is then performed. Results show that banking secrecy rules in Lebanon should be redefined in order to allow revealing customers' information in case of any suspicion through following an easy and simple procedure that does not harm the customers' confidentiality. Eventually, the increasing menace of terrorism and worldwide money laundering justify the need to amend these laws since without an unlimited cooperation of banks, the successful avoidance of threat is relatively difficult to be achieved. Finally, guidelines that interest scholars, banks, practitioners and legal authorities in Lebanon and elsewhere are provided.

Keywords: Banking secrecy, Money laundering, Banks, Economy, Lebanon 


\section{Introduction}

As a result of the terrorists' attacks that took place on the 11th of September 2001, the administration of the United States of America urged the United Nations to begin working on setting severe measures to put limits to the terrorism's financing. Indeed, on the 28th of September, the United Nations, through adopting the Resolution 1373, asked all states to cooperate through preventing, eliminating and criminalizing the terrorists' financing trials in their territories (Gates, 2006). One year after, the US congress adopted a variety of laws to combat money laundering and prohibited many persons and entities that are believed to be terrorists or have relations with terrorists from operating in its territories. Further, the Group of Seven (G7) which includes the United States, Canada, France, Germany, Italy, Japan, and the United Kingdom declared in 2002 their readiness to block the assets of terrorists and to criminalize them and then called on the Financial Action Task Force (FATF), at the Organization for Economic Cooperation and Development (OECD) in Paris, to include terrorist financing into its activities (ibid.).

As for Lebanon, The Lebanese government urged the Central Bank of Lebanon to establish by virtue of Law 318 of April 20, 2001 (Combating Money Laundering), the Special Investigation Commission (SIC), this being as an independent, legal entity with judicial status authorized to receive, analyze, and circulate reports of suspected operations with regards to money laundering as per the Law 318 declarations (Government of Lebanon, 2001). At this point, it is important to mention that under the provisions of this law, the acts of money laundering or terrorism as well as the financing or the contribution to the financing of terrorism are criminalized. Besides, SIC is given the exclusive right to freeze and lift banking secrecy on bank accounts, in accordance with applicable anti-corruption agreements and laws, particularly the United Nations Convention against Corruption and banking secrecy (Government of Lebanon, 2001). Still, Lebanon needs to join the Terrorist Financing Convention of the United Nations and to reconsider certain provisions of its laws mainly the banking secrecy law. However and despite the international movements towards a world free of terrorism and money laundering, Lebanon still strive to keep its banking secrecy law. This law prohibits banks to reveal any information related to the names and the assets of their clients without a written approval of this latter. Under this contradictory Lebanese situation and the international pressures and financial systems' changes, a Lebanese balance between the anti-money laundering rules and the banking secrecy law seems to be very difficult. At this point, one question comes into mind: What is the role of money laundering in the Lebanese economy and how the Lebanese Government will be will be able to preserve its longstanding banking secrecy practices and at the same time adopt the anti-money laundering rules and fight against the financing of terrorism? The significance of this research lies in the originality of the topic where no scholars have previously discussed this issue though the great need to identify the consequences of the twenty first century menaces and to analyze the most probable effects of the conflict between international pressures and local political regimes. In light of this gap and given the importance of the subject of study, the purpose of this research is to contribute to the field of study by examining the banking secrecy laws and analyzing their effects on the anti-money laundering rules in Lebanon. This should be of a 
great value to banks, practitioners and legal authorities in Lebanon and elsewhere allowing them to increase the stability of the economic sector and the security of the local financial systems.

\section{Literature Review}

Money laundering is the act of concealing the source of illegally acquired money to be reinvested in legal activities (Besson, 2009). This money usually comes from drug traffic, tax evasion, arms' trade, corruptions' practices and other illegal activities (ibid.). Money laundering process involves three phases: investment phase, stacking phase and integration phase. The investment phase consists of creating opportunities for the introduction of illegal money into the financial system. The stacking phase consists of accumulating many transactions to reduce the traceability of illegal funds. Finally, the integration phase aims to integrate the illegal funds in various sectors as investments (Lucy, 2003). The reasons why criminals aim for money laundering vary. Indeed, criminals tend to (1) hide their wealth so that they are not seized by the authorities, (2) avoid prosecution by distancing illegal funds, (3) avoid taxes levied on profits, (4) increase profits by reinvesting illegal money in legitimate businesses investments and (5) convert to legal through using laundered money to build a new business and provide legitimacy (Thiollet, 2002). In this effect, money laundering presents a variety of risks for countries which varies from social, to economic and political. For this, it is obvious for governments, banks and legal authorities to increase their efforts in fighting against money laundering and to discuss the related extant problems resulting from the existence of money laundering in various economies, Lebanon being part.

Some estimates for recent years show that the overall worldwide turnover of crime is estimated at \$ 1.000 billion per year (Vernier, 2013). Indeed, the financial volume of criminal origin is very huge. However, it is almost impossible to predict the exact amount of illegal generated profits per year due to the fact that the turnover related to fraud, tax evasions, arms' sales, illegal earnings and corruptions are difficult to be estimated. The worldwide increase of these illegal operations has reached imaginary figures in several countries, which influenced the financial situation, weakened the legitimate economy and put the phenomenon of banking secrecy under question. Money laundering exists in many countries around the world; these countries have been on the black list for being non-cooperative countries in the fight against money laundering as stated by FATF (FATF, 2006). Since June 2012, twenty countries are considered as being on the black list (Vernier, 2013). In this effect, the situation of Lebanon is still under question despite its participation in the international anti-money laundering programs. Money laundering operations have affected negatively the investors' confidence in major financial markets (Ping, 2004). This transfer of illegal money from one country to another (physical or electronic) has disguised through complex financial transactions. As a result, the United Nations stated that money laundering operations in recent years have a common trait; criminal organizations make extensive use of the opportunities offered by financial heavens and offshore banking centers to launder their assets, thus hindering prosecution services responsible for repressing (United Nations, 2015). Nevertheless with the features offered by modern technology such as free and easy access, anonymity and speed, the criminals are becoming very creative when it comes to developing new methods in order 
to hide the criminal nature of funds. To this end, international institutions such as FATF and IMF regularly publish typologies studies describing trends and techniques used by money launderers (Mani, 2003). With the increasing fight against money laundering at banks and tax heavens, as well as the lifting of banking secrecy in many countries, criminals are forced to turn to other intermediaries to launder money. These could be such as companies' fund transfer and money exchange offices (ibid.), purchase of goods in cash, electronic funds transfer, money orders, casinos, lottery, refining etc. Finally, it happens that criminals buy businesses that generate gross revenues through cash sales. This is the case of restaurants, bars, clubs, hotels and ATMs' companies. Then, they invest those funds obtained illegally by amalgamating them to support an honest business (Audouin, 2008).

Under the worldwide pressure exercised by the international legal organizations, the fight against money laundering has become a priority for banks which were obliged to increase their fight against money laundering by monitoring banking transactions. Article 324/1 of the Lebanese Criminal Code, as a result of this international pressure, added a new definition of money laundering and considered the fact of facilitating by any means the false justification of the origin of goods to a criminal who benefits directly or indirectly as a crime (Government of Lebanon, 2008). For ten years now, various laws have gradually strengthened their obligations in the fight against money laundering. Indeed, object 5 of Title 6 of the International Monetary and Financial Code declared the establishment of a department under the authority of the Minister of Economy, called "the Unit of Intelligence Processing and Action Against Illicit Financial Networks” (TRACFIN) in France (FATF, 1999). This department in collaboration with banks is required to report all operations including the identity of person in doubt, all transactions whose beneficiaries are not known and all transactions by persons or organizations related to the countries identified as non-cooperative in the international fight against money laundering (ibid.). Furthermore, FATF defined measures under the criminal justice and regulations that must be implemented to face these phenomena. Its recommendations include international cooperation and prevention measures to be taken by financial institutions and other actors such as casinos, real estate agents, legal professionals or accountants (FATF, 2000). In fact, FATF recommendations have emerged as a truly international norm against money laundering and terrorist financing (Coulibaly, 2011). The fight against money laundering and terrorist financing requires an approach that can at once take into account the many facets of the phenomenon and integrate a truly international dimension. Effective cooperation between public authorities and private secret organizations is essential. The FATF standards have been approved by international bodies such as the UN, IMF and the World Bank. The position of the FATF, the vanguard of efforts internationally to combat the financing of terrorism has been further reinforced by the call launched in September 2009 by officials from the Group 20 (G20) which is a group of nineteen countries (South Africa, Canada, Mexico, USA, Argentina, Brazil, China, Japan, South Korea, India, Indonesia, Arabic Arabia, France, Germany, Italy, UK, Russia, Turkey and Australia) and the European Union whose ministers, heads of central banks and heads of state meet regularly for that action be taken against non-cooperative countries and territories in the context of the economic crisis (United Nations, 2015). The FATF Plenary has responded in October 2009 by taking action on the 
points mentioned in the G20 statement. In response to the request of the G20 for identification of countries and territories concerned, the FATF published in February 2010 a "FATF Public Statement" and a document entitled "Improving compliance with AML standards / CFT (Anti Money Laundering and Countering Financing of Terrorism). Also in response to the call of the leaders of the G20 countries, the FATF has agreed to publish information to better awareness of the means to multiply the effectiveness of AML / CFT to the service of the fight against corruption and permanent work of the financial Action Task Force to strengthen standards (FATF, 2013). The FATF's policy which aims to involve many partners in the definition and implementation of its standards, maintains a very close dialogue between its members who are mainly the FATF-regional bodies, international financial institutions, other organizations with observing status and the private sector representatives. In October 2009, the FATF published screening of new lines of treating life insurance implementation of a risk-based approach to fight against money laundering and terrorist financing. Similar guidelines in other sectors have been published in previous years (ibid.). In February 2010, the FATF has approved two new notes of the series of best international practices, "detection and prevention of illegal cross-border movement of cash and bearer negotiable instruments” and “confiscation” (FATF, 2013).

Furthermore, knowing that AML/CFT laws impose a number of obligations as aforementioned (i.e., identifying customers, reporting suspicious transactions, record keeping and others), it becomes clear that in order to comply with these obligations, banks face high costs and increasing complexities. For example, reporting suspicious transactions may undermine customer trust. The strict rules related to establishment of correspondent banking relationships may limit the ability of banks to expand their corresponding banking networks and worldwide businesses. Indeed, it has been noted that reporting fraud against banks, investigating about fraud and tracing and confiscating criminal proceeds came into the principles of banking secrecy (FATF, 2010). The inroads into banking secrecy offer serious threats to democracy, and more specifically to the traditional customer-banker relationship. It is widely known that combating money laundering and terrorist financing is in conflict with the secrecy rules. Banking secrecy is a privilege for customers while fighting against crimes is a necessity for security (ibid.). However, it is noticed that through years, criminals and money launderers have taken big advantage of banking secrecy laws to do their illegal transactions. In fact, banking secrecy laws have provided a big help for criminals to avoid being detected. In addition, banking secrecy and confidentiality have been used as barriers against obtaining information and cooperation in criminal investigation (ibid.).

According to studies conducted in the United States, banking secrecy helps criminals to proceed in their illegal operations through (1) anonymous accounts that no one can know the owner unless the customers themselves reveal the information, (2) accounts in which a lawyer puts himself between the bank and the customer, thereby protecting the customer identity and (3) accounts which are coded in a way that only the top management of the bank knows the owner and the secrecy laws prevent the owner from revealing the information (United Nations, 2015).

By knowing this, it is obvious to conclude that banking secrecy should be excluded in case 
the disclosure of confidential information is necessary for detecting and prosecuting criminals. Besides, banking secrecy is being used in many cases to obstruct cooperation and information sharing in combating money laundering.

In this issue, the last current years have witnessed the development of various international proposals to solve the problem of banking secrecy. These proposals had in common that all banks are asked to cooperate for fighting against money laundering and cannot invoke the principle of banking secrecy to refuse to give confidential information to the legal authorities. Besides, the FATF declares clearly that banking secrecy should be lifted in order not to inhibit the implementation of its aforementioned recommendations. Therefore, banking secrecy laws need to be excluded worldwide to allow the sharing of information between competent authorities and between financial institutions (FATF, 2010).

However, in Lebanon, banking secrecy laws still state that if a bank breaches its duty of secrecy, it could be liable for common law damages in addition to the right of the customer to sue the bank for offense. It is a defamation to disclose any information or document related to the account of a customer. Nevertheless, banking secrecy laws can be lifted in case (1) the customer has given a written permission to allow disclosing his or her information; (2) the customer is declared bankrupt; (3) when there is an action by the bank against the customer; (3) when information is related to credit facilities; (4) when disclosure is authorized by the Central Bank of Lebanon for court reasons and money laundering suspicions (Central Bank of Lebanon, 2016). It can be said that the government has allowed such exceptions to the secrecy rules in order to (1) collaborate with the international pressures for fighting against money laundering, (2) facilitate police investigation and (3) decrease malpractice in the Lebanese banking sector.

\section{Research Methodology}

The best method to be used to test the relationship between banking secrecy and the fight against money laundering in Lebanon is the qualitative research. This choice comes down to the nature of this research concerning the Lebanese banking sector and to the need to tackle the Lebanese banks' directors and top management in order to discuss the relevant issues under investigation.

There are many methods of qualitative research, the most famous being (1) group meetings or focus groups, (2) face to face interviews, (3) Delphi and (4) all ethnographic methods such as the direct or indirect observations, photography, story etc. In this study, the method of face-to-face interview with open ended questions has been chosen as the best fit in this case so as to reach the population of banking directors and top management that cannot be gathered into one focus group due to their big responsibilities and tough schedules. This should help in gathering different opinions related to the role of Lebanese banks especially in fighting against money laundering and the balance to keep with bank secrecy laws.

Thus, the target population of the study included directors and top management of the Lebanese banks. As of February 2016, four directors chosen based on a purposive sampling technique from various Lebanese banks were contacted for a face to face interview. 
Data analysis were conducted through using Nvivo, a computer-aided text analysis software program which can store data in a systematic way, provide hierarchies and structures of data, conduct specific analytical tasks and respond to questions that the researcher inserts to the data, therefore facilitating the life of the qualitative researcher and enhancing research productivity (Gummesson, 2005).

\section{Results and Discussion}

This section is divided into two parts where the first consists of describing the results of the interviews and the second draws an analysis of the gathered results.

\subsection{Results of the Study}

Since ten years ago, the Lebanese banks have been holding a burden of misbalance between the Lebanese banking secrecy rules and the anti-money laundering regulations. However, only the minimum was accomplished so as to comply with the international legislations. Today this issue has become an essential dilemma that plays a primordial function in the activities of monitoring and risk assessment. Banks continue to invest elsewhere to adapt their systems to the new methods of money laundering. In order to meet the objective of the study, the following questions were asked on the four directors who were selected from four different Lebanese banks: (1) how does your bank assure its customers of banking secrecy under this international pressure against the banking secrecy rules and money laundering?, (2) what does money laundering mean to you today?, (3) how to fight against money laundering?, (4) is your bank aware of the importance of fighting money laundering?, and (5) what is the impact of money laundering in the Lebanese economy?

As for question 1, the first director reported that the bank customer is always assured by bank secrecy rules. According to the principles and practices that govern the banking industry, a bank must know its clients. At the same time, customers consider their bankers in general as a great confidant and a key economic partner; a person who is consulted for optimization of investments. The second director stated that the banker must provide nonstop advices to clients, that duty cannot be accomplished successfully unless he has a perfect knowledge of the client. A great confidentiality in the special services of the bank must be guaranteed. The right of the customer to remain discreet, not to declare his true identity, not to be required to economically justify his fortune should be respected. So an anonymous and confidential code ensures communication with the bank. The third director said that in order to answer the question, he must think as a client. "As a customer and citizen, I can hardly accept a situation where my bank, regardless of the quality of its services, contributes to the existence of a lawless world. I don't accept my bank to protect criminals and to offer them facilities to bleach money under the name of banking secrecy”. The fourth director stated that he trusts the established relation between the bank and its clients, coupled with the ability to adapt to technological changes and to improve the quality of services, which makes the bank a very dynamic world. This dynamic bank is also perpetuated by the tradition of secrecy that is required and the banker whose influence still comes out more strengthened after innovation. "Our client is guaranteed by his confidences with the banker who should never fail, thanks to banking secrecy that prevents the banker from disclosing information”. 
As for question 2, the first director stated that this is a problem that finds its way around the world. The money laundering is rooted in the different techniques of crime (drug traffic, weapons, extortion, tax evasion...). These usually happen more easily in poor countries, because poverty is the main reason for using the laundering of money gains; but unfortunately these illegal gains lead to prison and financial losses. Money launderers believe that their operations will not be easily discovered and surveyed. The second director said: "Since ten years ago, Lebanese banks have been considered as protectors of banking secrecy rules and at the same time ready to do the maximum so as to comply with the legislations against money laundering though confidentiality attracts customers”. The third director declared: "As we know, money laundering is one of the quietest and most virulent scourges of our time. The role of the bank begins by controlling the means that allow criminals of all kinds to disguise the origin of the funds they hold. It must also be able to prevent criminals to retain these funds and indeed our bank plays a key role in ensuring that and protecting its customers". The fourth director stated: "Money laundering is to recycle or transfer the property and proceeds of crime in order to hide its nature and illicit origin. The banking sector has increased its commitment to fight against money laundering. Each bank must do everything possible to fight against this crime”.

As for question 3, the first director announced: “Our wrestling team fights against money laundering using securities’ firms, insurance companies, banks and other financial institutions to adopt a compliance framework so that they can all fulfill their obligations of combating money laundering and terrorist financing. These obligations consist of prevention, identification and intervention. We support many institutions in the assessment and implementation of compliance programs with national and international laws on money laundering. We also assist in investigations concerning complex fraud and money laundering”. The second director announced that the court case called the Path, and especially its financial projections, will at least have to put the spotlight on the failures of the banking sector in combating money laundering. The third director stated that confidentiality arising from the banking secrecy rules causes banks to be vulnerable for money laundering trials. The fourth director supported the idea that banks are required to fight against money laundering by monitoring banking transactions. By definition, money laundering is the fact of facilitating by any means the false justification of the origin of goods or income of the perpetrator of a crime or offense that has provided to it a direct or indirect profit. The fight against money laundering is inseparable from that against corruption; the products of the latter inexorably follow the circuits of money laundering.

As for question 4, the first director declared: "Yes of course, the banking secrecy and the fight against money laundering are very important. They have common results related to criminals in case of non-compliance. The fight against money laundering is considered therefore as the preservation of bank secrecy". The second director announced: "Our work in these days is stressing on answering the following questions: what?, why?, how?, when? and how much?. This aims to protect our clients against any fraud”. The third director declared: "The banks need to realize that they cannot tell their customers that they are effectively fighting against money laundering and on the other hand invoke when a scandal erupts the 
difficulties to apply what should be done". The fourth director assured that his bank takes into consideration the laws that reinforce the obligations in the fight against money laundering. A great caution is manifested whenever an operation is proposed so as to ensure the origin of each transaction. This is particularly the case when an operation is mainly carried out in cash.

As for question 5, the first director stated that money laundering contributed to the weakening of the Lebanese national income, which explains the drain of the national economy and prohibits the increase in economic productivity. The second director declared that money laundering plays a key role in the instability and the decline of financial markets in Lebanon; it weakens the value of the local currency. Furthermore, the tax evasions lead to a decrease in the financial resources of the country and are a major reason behind the imbalance between spending and revenue. The third director said that money laundering leads to significant capital evasion to foreign countries and causes the imbalance and instability between savings and consumption. The fourth director assured that money laundering is a broad term for a decrease in the economic activity of a country; however, it weakens the local currency value and leads to unstable financial markets, which subsequently leads to an imbalance between spending and revenue.

\subsection{Discussion}

It is important to note that in this section, the researcher focuses on capturing what is special and unique for each subject under investigation instead of standardizing the interviews' materials so as to compare the various opinions of interviewees. Indeed, triangulation technique is used to ensure that the information gathered is rich, robust, comprehensive and well developed (Baschwitz, 2010).

Based on the interviews conducted and the different responses received from these four directors, and after studying and analyzing the situation of each of the Lebanese banks, it is obvious to resume that the various Lebanese banks and financial institutions in the country as well as the Lebanese government and legal authorities are working to reassure the Lebanese and foreign investors on the competence of Lebanon and the region to meet the many economic challenges in times of crisis.

Lebanon adopts a strict legislation on banking secrecy. This law is the basis of the Lebanese banking legislation. To lift banking secrecy in Lebanon, only few possibilities are available. This applies to any account holder in Lebanon whether the holder is Lebanese or foreign. The legislation on banking secrecy was first intended to repatriate Lebanon's assets held by Lebanese abroad and results were encouraging especially that every year, the Lebanese banks keep welcoming huge amounts deposited by Lebanese working overseas. Besides, it is important to mention that Lebanon is one of the few countries which did not suffer the negative effects of the global financial crisis in 2007.

The Lebanese government in collaboration with the Central Bank of Lebanon works on implementing all the necessary means to support the economy and to align with the international legislations against money laundering. However, extant banking secrecy laws are still on the top of discussions. In this effect, it is obvious to resume that the efforts of the 
Lebanese authorities to assure success in regards to the Lebanese economy are not enough due to the failure of the authorities to lift banking secrecy laws as suggested by many international organizations. Indeed, banking secrecy laws prevent the effective identification of the customer and the serious control of the customer's activities.

In support of the fight against money laundering, the banking secrecy laws in Lebanon should be reconsidered because of its key role in providing an indirect support to the bleaching process. This reconsideration is already requested by the global horizon. The importance of the issue is recognized by the Lebanese authorities but the burden of the requested repairs weighs on the state in addition to the damages that will follow.

Due to globalization, it becomes more and more difficult to control the money laundering trials unless all countries work together to fight the geographical expansion of this phenomena and to reduce the resulting risks especially in terms of security. In this effect, the FATF through its fight against money laundering helps to better define the illicit nature of capital flows. The Lebanese banks in collaboration with the international organizations aims to draw a relatively accurate picture of the flow of organized crime and works on offering reliable data to fight money laundering.

According to the aforementioned analysis and the conducted interviews, it is clear that the fight against money laundering has become increasingly important to banks and tax heavens, as well as the lifting of banking secrecy. Once this is accomplished, criminals will be forced to turn to other intermediaries to launder their money. Furthermore, it can be concluded that money laundering weakens national income and affects negatively the national economy (a weakness of the productive sectors due to poor savings and investment). On the other hand, the fair of capital drain due to the lifting of banking secrecy increases the imbalance between savings and consumption, and contributes to the instability of monetary and financial markets, weakening the value of the local currency.

\section{Conclusion}

Lebanon is working hard to comply with the current requirements of anti-money laundering so as to improve its financial situation, to modernize the state tools for combating money laundering and to allow the Lebanese economy to return to the international competition. Concrete results appear due to the intelligence and experience of the Lebanese authorities and more specifically due to the efforts of Mr. Riad Salameh the governor of the Central Bank of Lebanon. Anti-money laundering regulations in addition to constraints imposed by the agencies responsible for anti-money laundering threaten the future of banking secrecy. Another menace remains; the link between politics and economy and the interaction between private and public sectors in the name of freedom and democracy that can potentially be affected.

According to FATF, the Lebanese compliance with the international anti-money laundering rules has led to a gradually reduced rate of money laundering in the country. The development of the law 318 in 2001 has created SIC to investigate the operations of money laundering and punish criminals. Hopefully, the black list of FATF will be empty to finally 
reach a global economic prosperity in the coming years.

Lebanon aim is to maintain and enhance the reputation and solidity of its banking sector at the international level without having to change its banking secrecy laws that remain largely absolute. Since the development of the law 318, Lebanon has been able to strengthen the Lebanese economy, making it more effective on the national level and to strengthen its relationships internationally. But the question of banking secrecy is still a debate although Lebanon has adopted the legislations against money laundering because lifting this banking secrecy is still restricted to the SIC who is the only authority to judge. On the other hand, the elimination of banking secrecy might lead to loosing one of the best assets of Lebanon-the banking sector.

The law of banking secrecy allowed the Lebanese banking sector to grow and to play a key role in the Arab world. Indeed all Arab countries including the closest geographically such as Egypt, Iraq and Syria, faced a period of political and military instability which led ultimately to nationalization phenomena and therefore to capital flight and Lebanon was the first beneficiary.

The adoption of a new amendment to the anti-money laundering regulations to extend the scope of the crime to include offenses committed outside the country will obviously strengthen the obligations of the banks towards money laundering prevention and will stress the need to effectively participate in the efforts of the international community to fight against money laundering and terrorism financing. This should be the first step that can be a basis for further amendments that may take place in order to reach a phase where Lebanon can be able to eliminate its banking secrecy laws without the fear of loosing the stability of its banking sector.

Finally knowing that the international organizations fighting against money laundering and terrorism financing are exercising an extremely increasing pressure on the Lebanese banking sector, one question arises. Till when the Lebanese banks applying all the international rules to fight against money laundering will be able to maintain the rigidity of the sector without lifting its banking secrecy laws?

\section{References}

Audouin, O. (2008). Guide opérationnel de la lutte anti-blanchiment dans la banque. Paris: Éditions AFGES.

Baschwitz, B., Ketele, M., \& Godelet, E. (2010). Comment me documenter? Fomateurs, Enseignants, Etudiants. Bruxelles, Belgique: De Boeck.

Besson, S. (2009). Le secret bancaire: La place financière suisse sous pression. Lausanne: Presses polytechniques et universitaires romandes, collection Le savoir suisse, Suisse.

Central Bank of Lebanon. (2015). Central Bank of Lebanon Annual Report 2014-2015.

Coulibaly, S. (2011). Le secret bancaire et la lutte contre le blanchiment des capitaux. Sayoncoul. 
El Chalouhi, N. (2014). Le secret bancaire Libanais résistera-t-il au blanchiment d'argent? Bulletin FMI.

Financial Action Task Force on Money Laundering. (1999). Policy Brief: Money Laundering.

Financial Action Task Force on Money Laundering. (2000). Report on Money Laundering Typologies 1999-2000.

Financial Action Task Force on Money Laundering. (2002). Guidance for Financial Institutions in Detecting Terrorist Financing.

Financial Action Task Force on Money Laundering. (2006). Annual Review of Non-Cooperative Countries and Territories 2005-2006.

Financial Action Task Force on Money Laundering. (2010). Annual Report 2009-2010.

Financial Action Task Force on Money Laundering. (2013). Annual Report 2012-2013.

Gates, A. (2006). Buildings Rise from Rubble while Health Crumbles. The New York Times.

Gilmore, W. C. (1999). Dirty Money (2éme edition). Paris: Dunod.

Government of Lebanon. (2001). Law no. 318 of April 20, 2001 "Fighting Money Laundering”. Extract from the Official Gazette-Number 20-April 26, 2001.

Government of Lebanon. (2008). Article no. 324/1 of the Lebanese Criminal Code.

Gummesson, E. (2005). Qualitative research in marketing. European Journal of Marketing, 39(3/4), 309-327. https://doi.org/10.1108/03090560510581791

Habib, O. (2011). SGBL to merge with Lebanese Canadian Bank. The Daily Star.

Kopp, P. (2006). La lutte contre le blanchiment: in "Analyse économique comparée de la lutte anti- blanchiment: droit continental”. Chaire Régulation de Science, p. 7.

Lucy, C. E. (2003). L'odeur de l'argent sale. Paris: Eyrolles.

Maalouf, A. (2015). Il reste beaucoup à faire pour lutter contre le blanchiment d'argent. L'Orient Le Jour.

Mani, M. (2003). L’Union Européenne dans la lutte contre le blanchiment d'argent. Paris: L'Harmattan.

Manouk, V. (2004). Genèse du processus de blanchiment d'argent-Analyse conceptuelle: traces de l'expression en économie médiévale pré-capitaliste. Revue Internationale de Criminologie et de Police Technique et Scientifique (RICPTS), 4(3), 323-338.

Nashabe, O. (2006). Siksters of Mercy: The story of Rana Koleilat and Joumana Ayyas, AL-Raida Magazine, 23(113), 25-27.

Ping, H. (2004). Banking secrecy and money laundering. Journal of Money Laundering Control, 7(4), 376-382. http://dx.doi.org/10.1108/13685200410810074 
Robinson, J. (1995). Les Blanchisseurs. Paris: Presses de la Cité.

Thiollet, J. P. (2002). Beau linge et argent sale_Fraude fiscale internationale et blanchiment des capitaux. Paris: Anagramme éditions.

Thony, J. F., \& Koutouzis, M. (2005). Le blanchiment, Que sais-je. Paris: PUF.

United Nations. (2015). Financial heavens, banking secrecy and money laundering, Global program against money laundering. Office for drug control and crime prevention publications.

Vernier, E. (2008). Techniques de blanchiment et moyens de lutte. Paris: Dunod.

Vernier, E. (2013). Techniques de blanchiment et moyens de lutte. Paris: Dunod.

Warde, I. (2006). Ce que cache l’affaire “Clearstream”. Le Monde Diplomatiqu.e, No. 627.

\section{Copyright Disclaimer}

Copyright for this article is retained by the author(s), with first publication rights granted to the journal.

This is an open-access article distributed under the terms and conditions of the Creative Commons Attribution license (http://creativecommons.org/licenses/by/3.0/). 